\title{
PERAN KEPUSTAKAAN DAN PERPUSTAKAAN \\ DALAM MEMBANGUN PERADABAN ISLAM \\ (SEBUAH TINJAUAN HISTORIS PERADABAN PERPUSTAKAAN \\ ISLAM)
}

\author{
Sahidi \\ Program Studi D-3 Perpustakaan \\ Fakultas Keguruan dan Ilmu Pendidikan \\ Universitas Tanjungpura \\ sahidiip@fkip.untan.ac.id
}

\begin{abstract}
Abstrak
Rintisan kepustakaan diawali dengan pencatatan teks keagamaan dan non keagamaan. Perkembangan perpustakaan terus beransur pada masa pemerintahaan Dinasti Umayah dengan berdirinya Perpustakaan yang pertama yaitu perpustakaan al-Zuhri. Penguasa pada masa Khalifahan Bani Abbasiyah terdorong untuk mendirikan sebuah perpustakaan sebagai pusat riset ilmu pengetahuan. Faktor-faktor pendorong kemajuan kepustakaan dan perpustakaan Islam pada masa itu tidak terlepas dari kebijakan-kebijakan dan kepedulian pemerintah. Kebijakan pada pada masa itu, khususnya pada masa abbasiyah lebih mendukung ke arah kemajuan dan pengembangan ilmu pengetahuan dengan strategi mengirimkan ilmuan untuk melakukan sebuah riset terhadap ilmu-ilmu yang ada di negara-negera luar seperti Yunani dan diterjemahkan ke dalam bahasa sendiri yaitu bahasa Arab, kekayaan negara yang mendukung kesejahteraan masyarakat, dan kesadaran akan pentingnya ilmu pengetahuan bagi masyarakat. Keberadaan perpustakaan pada awal Islam hingga pada masa kejayaan Islam telah menghasilkan karya-karya, baik itu ilmu keagamaan maupun science, sehingga pada masa itu para ilmuanilmuan muslim memberikan kontribusinya terhadap kemajuan Islam melalui karya-karya mereka. Peran tersebut dapat dilihat bahwa perpustakaan pada masa itu dapat menjadi sebuah kreatifitas bagi individu untuk mendayagunakan potensi-potensi yang ada dengan menjadikan perpustakaan sebagai pusat penerjemahan, pusat pembelajaran, dan pusat penelitian.
\end{abstract}

Kata Kunci: Kepustakaan, Perpustakaan, Peradaban Islam

\begin{abstract}
Literature pioneering begins with recording religious and nonreligious texts. The development of the library continued during the reign of the Umayah dynasty with the establishment of the first library, the al-Zuhri library. The rulers at the time of the Abbasid Caliphate were encouraged to establish a library as a center for
\end{abstract}


scientific research. The driving factors for the advancement of Islamic libraries and libraries at that time were inseparable from government policies and concerns. The policies at that time, especially during the abbasiyah era, were more supportive towards the progress and development of science with a strategy of sending scientists to conduct research on sciences in foreign countries like Greece and translated into their own language, namely Arabic wealth of the state that supports the welfare of society, and awareness of the importance of science for society. The existence of libraries in the early days of Islam until the heyday of Islam had produced works, both religious and scientific sciences, so that at that time Muslim scientists contributed to the progress of Islam through their works. This role can be seen that the library at that time could be a creativity for individuals to utilize the existing potentials by making the library a translation center, learning center, and research center.

Keywords: Literature, Library, Islamic Civilization 


\section{Pendahuluan}

Sejarah telah mencatat, bahwa keberadaan perpustakaan dalam sejarah islam telah memberikan dampak terhadap peradaban dan ilmu pengetahuan dunia, khususnya di kalangan ummat Islam sendiri. Hal ini dibuktikan dengan kejayaan Bait Al-Hikmah di Baghdad sekitar abad II H. Wacana perpustakaan Islam banyak ditemukan pada literatur klasik. Isu-isu tersebut seperti munculnya perpustakaan muslim yang berbasis keagamaan dari awal pembentukan masyarakat Islam sendiri, karena memang pada dasarnya terdapat pengaruh keagamaan terhadap praktik-praktik kepustakaan pada masa itu. Praktik kepustakaan pada masa itu seperti penyediaan koleksi-koleksi keislaman berupa mushaf al-Qur'an di mesjid dan musholla serta tempat ibadah lainnya yang tidak luput dari pengaruh keagamaan pada praktik kepustakaan (Masruri, 2006: 2). Kepustakawanan dalam konteks Islam bersandar dari tradisi teks dan konteks. Menurut Hak (2015: 31-32) tradisi teks lebih awal daripada tradisi konteks, dimana tradisi teks dapat ditelusuri melalui tradisi keagamaan (Islam) sendiri, yaitu menulisan mushaf al-Qur'an dan Hadits serta peradabannya. Semua ini menunjukan adanya pengaruh keagamaan terhadap praktik kepustakaan dalam bentuk teks-teks keagamaan yang kemudian menjadi sebuah konteks kemajuan ilmu pengetahuan hingga saat ini.

Perkembangan pengetahuan dan keilmuan tentunya tidak lepas dari pengaruh adanya perpustakaan dan Islam. Sebagai upaya untuk membangun peradaban islam, umat islam pada masa itu menghadirkan sebuah perpustakaan sebagai icon dari adanya ilmu pengetahuan. Menurut Zulaikha (2008:2) Perpustakaan dijadikan sebagai agen yang membawa perubahan bagi masyarakat luas, dimana perubahan tersebut sangat diharapkan oleh masyarakat luas dalam perannya untuk 
membentuk karakter masyarakat arab yang lebih baik. Perpustakaan dan kepustakaan islam memang pernah berjaya pada beberapa abad lamanya yang kemudian mengalami kemunduran yang disebabkan oleh beberapa faktor yang tidak bisa diatasi oleh umat islam pada masa itu. Perkembangan ini dimulai pada masa perintisan, pembentukan dan pembinaan serta terjadi kemunduran yang mengakibatkan umat islam mengalami stagnasi ilmu pengetahuan. Semua itu merupakan proses yang pernah dilalui oleh umat islam pada masa membangun peradaban pengetahuan yang kemudian lahir sebuah peradaban baru bagi ummat islam yang mengagungkan ilmu pengetahuan bagi umat islam sendiri dan meluas ke berbagai wilayah di belahan dunia seperti eropa.

Perhatiaan yang sangat tinggi terhadap ilmu pengetahuan yang diorientasikan untuk pendidikan dan menjunjung tinggi kehormatan terhadap manuskrip-manuskrip keilmuan menjadi asas tumbuhnya kembangnya perpustakaan islam pada masa itu (Zuhrah, 2008: 66). Keberadaan literatur seperti buku bukan hanya dijadikan semata-mata sebagai media, tetapi juga memiliki nilai-nilai moral yang melandasi perhatian kepada literatur buku. Perhatian ini mengharuskan adanya diseminasi dan pelestarian literature buku sebagai tindakan yang mendukung kemajuan ilmu pengetahuan dan pendidikan di masa yang akan datang. Dapatlah dikatakan bahwa keberadaan perpustakaan Islam pada masa itu menjadi pusat ilmu pengetahuan. Keberadaan perpustakaan pada masa itu difungsikan sebagai sarana belajar (learning centere) bagi umat Islam dalam membangun peradaban dan kejayaannya sehingga bertahan beberapa abad-abad. Sejarah mencatat bahwa terdapat informasi dan ilmu pengetahuan yang tidak terdokumentasikan dengan baik oleh umat Islam, sehingga tatanan umat Islam baik aspek ekonomi, sosial, politik, budaya 
dan aspek kehidupan yang lain mengalami stagnasi yang pada akhirnya umat Islam hanya menjadi umat pengikut dari bangsabangsa yang maju, yang dalam hal ini adalah dunia barat yang sesungguhnya kemajuan barat sendiri merupakan pengadopsian dari karya-karya umat Islam sendiri.

\section{TINJAUAN PUSTAKA}

\section{Sejarah Kepustakaan dan Perpustakaan Islam}

Praktik kepustakaan kepustakawanan yang berupa tradisi dan pelestarian informasi pada suatu media sebenarnya telah terjadi sejak awal datangnya agama Islam. Tradisi yang muncul pada masa itu adalah tradisi teks yaitu berupa penulisan wahyu Al-Quran, dan teknik bagaimana melestarikan media penyimpanan informasi tersebut seperti kulit binatang, batu, tulang unta dan media lainnya yang dapat difungsikan sebagai preservasi informasi. Nabi Muhammad SAW., baik sebagai rasul maupun pemimpin masyarakat, sangat memperhatikan terhadap perlunya menyimpan dan melestrikan dokumen. Menurut Hak, (2015: 50) tradisi penulisan ini sendiri didasarkan pada perintah Nabi Muhammad s.a.w. agar menuliskan al-Qur'an. Ini adalah tahap pertama tradisi penulisan dalam Islam. Pada masa pra Islam, masyarakat jahiliyah belum menjadikannya sebagai tradisi. Hal ini bukan berarti pada masa pra Islam tradisi tulisan tidak ada sama sekali. Bangsa Arab Kuno, Arab Selatan telah meninggalkan bangunan-bangunan peradaban dan tradisi bangsa Arab yang sebagiannya tertulis di batu-batu nisan, prasasti dan lain-lain. Semua ini menujukan adanya tradisi menulis sebelum Islam datang.

Penulis menyimpulkan bahwa perpustakaan pada masa Nabi Muhammad s.a.w dan para sahabatnya, perpustakaan 
dalam pengertian yang ada seperti pada masa kini tidak di temukan. (Qalyubi,2007: 48). Cikal bakal adanya perpustakaan sudah ada pada masa sebelumnya yang ditandai dengan adanya:

a. Terdapat wahyu Allah yang pertama memerintahkan Nabi Muhammad SAW untuk membaca (Iqra').

b. Terdapat sahabat seperti Zaid bin Tsabit, Ubay bin Ka'ab, dan Khalid bin Walid yang diangkat langsung oleh Rasulullah SAW, untuk menulis mushaf Al-Quran.

c. Rasulullah SAW memerintahkan kepada tawanan perang Badar untuk mengajari anak-anak Muslim membaca dan menulis.

d. Munculnya gagasan menulis mushaf Al Qur'an dalam bentuk pribadi seperti Mushaf Ubay bin Ka'ab, Mushaf Ibnu Mas'ud, Mushaf Ibn Abbas dan pada akhirnya melahirkan Mushaf Utsmani yang di salin menjadi 4 Mushaf. Pada masa Rasulullah SAW muncul keinginan menulis Al Qur'an dalam bentuk mushaf pribadi seperti Mushaf Ubay bin Ka'ab, Mushaf Ibnu Mas'ud, Mushaf Ibn Abbas dan pada akhirnya terdapat mushaf Usmani yang terdiri dari empat mushaf. Ada riwayat yang menyatakan bahwa penyebaran mushaf tersebut ke kota Madinah, Makkah, Kuffah, Basrah dan Damaskus. Mushaf Usmani yang tersebat tersebut di jadikan referensi oleh seluruh Umat Islam sampai saat ini. Peristiwa inilah yang mendorong umat Islam gemar menulis dan membaca yang merupakan cikal bakal semangat tradisi kepustakaan dalam membangun peradaban.

Selain pencatatan wahyu, juga adanya kodifikasi hadits yang terjadi pada masa pemerintahan Khalifah Bani Umayah yaitu pada masa pemerintahan Umar bin Abdul 
Aziz ( 99-101 M ) sekitar awal abad II H. Hal tersebut merupakan sebagai tanda adanya kepustakaan pada awal Islam. Penulisan hadist tersebut terjadi dari masa awal sahabat Nabi sampai akhir hayat Nabi Muhammad s.a.w. walaupun pencatatan pada masa itu masih belum terintegrasi (Hak, 2015: 51). Masa ini merupakan masa pembentukan dan pembinaan Perpustakaan. Menurut Qalyubi, (2007: 49-50) pada masa ini terdapat hal yang melatarbelakangi pembentukan dan pembinaan perpustakaan antara lain sebagai berikut:

a. Adanya pembukuan Al-Quran sehingga timbul keinginan masyarakat muslim, untuk memahami isi Al-Quran sesuai dengan yang dipahami dan dilaksanakan oleh Rasulullah s.a.w. Muncul keinginan dari sebagian ulama untuk menghimpun hadits-hadits Rasul meskipun mendapat tantangan dari ulama pada masa itu karena ada larangan pembukuan hadits yang melarang penulisan yang bersumber dari Rsulullah selain AlQuran. Pada masa khalifah Umar bin Abdul Aziz (wafat $672 \mathrm{M})$, ia memerintahkan Muhammad bin Muslim bin Syihab az-Zuhri al-Madani (wafat 695 M), agar menghimpun hadits-hadits dan menulisnya.

b. Gagasan Ibn Syihab az-Zuhri kemudian juga diikuti oleh para ulama lain, mereka rela pergi jauh untuk mendapatkan hadist yang nantinya akan mereka himpun. Himpunan Hadits ini nantinya dikenal dengan Sahih Bukhari, Shahih Muslim, Sunah Abu Daud, Sunan At-Turmudzi.

c. Gerakan penerjemahan mucul yang dipelopori oleh Khalifah al-Mansur dari Daulah Abbasiyah. Khalifah menginstruksikan pada ornag Persia yang baru menganut agama Islam agar melakukan penerjemahan 
literature Persia ke dalam bahasa Arab. Literatur tersebut mencakup bidang atrologi, tentang ketatanegaraan dan politik, serta tentang moral, seperti Kalila wa Dimna dan Sindhid. Penerjemahan juga dilakukan pada literature yang berbahasa Yunani karya Aristoteles Logika karya Aristoteles, Almagest karya Ptolemy, Aritmetic karya Nicomachus dari Gerasa, Geometri karya Euclid. Gerakan semacam ini juga diikuti oleh. Gerakan penerjemahan itu didukung oleh khalifah al-Ma'mun, Khalifah rela memberi upah yang sangat besar kepada orang yang berhasil menerjamahkan literatur, bahkan membayar setara bobot emas pun pernah khalifah lakukan untuk hal itu. Sehingga tidak heran jika banyak tambahan rujukan atau literature baik rujukan keislaman dan rujukan umum.

Perhatian Nabi Muhammad SAW juga pada pengadministrasian dengan membuat catatan-catatan tertulis kegiatan-kegiatan penting yang harus terdokumentaskan dengan baik. Rasulullah pernah meminta kepada nama-nama nama-nama orang-orang yang masuk Islam, dan Rasulullah juga meminta daftar tentara perang (Rifai, 2013: 59). Pencatatan tentang utang piutang, sewa menyewa tanah, perjanjian (damai dan lain-lain), hartaharta sedekah, surat-menyurat (korespodensi), baik antara kabilah, suku-suku Yahudi maupun surat dari raja-raja kepada Nabi Muhammad SAW yang telah dimulai sejak beliau tinggal di Madinah (Hak, 2015: 55). Meskipun demikian hal ini tidak dapat dikatakan secara langsung bahwa pada masa itu sudah ada tempat khusus sebagai perpustakaan.

Ulasan di atas merupakan indikator bahwa kepustakaan pada masa awal lahirnya Islam sudah ada 
dengan bukti-bukti penulisan teks-teks keagamaan dan non keagamaan Islam tentu hal ini juga sudah terlihat jelas bahwa pad masa Rasulullah sistem administrasi atau tata kelola dokumen-dokumen yang berkaitan dengan pemerintahan pada masa itu sudah dikelola sesuai dengan prosedur yang berlaku oleh orang yang bertugas mencatat dokumen-dokumen tersebut mirip dengan pustakawan atau arsiparis yang ada pada masa kini. Akan tetapi apakah memang pada masa itu terdapat kegiatan yang memang khusus mengelola dokumen atau pembukuan seperti perpustakaan yang ada pada masa sekarang ini.

Selain indikator yang telah diulas di atas adanya kesusastraan yang tumbuh dan berkembang pada masa itu adalah mesjid. Masjid pada masa itu difungsikan sebagai tempat menyampaikan informasi, proses peradilan, dan kegiatan keagamaan lainnya seperti pembelajaran keagamaan. Proses pendidikan di masjid berjalan dengan sistem khalaqah bagi kaum muda, para ilmuan juga memberikan pelatihan dan pencerahan keilmuan untuk menjalankan ajaran Islam yang sebenarnya, dan menyampaikan hasil penelitian (Masruri, 2006: 59). J. Pedersen, (1996: 37) berpendapat bahwa berakarnya kehidupan intelektual pada agama, yang merupakan dasar masyarakat Islam, menciptakan rasa hormat pada ilmu sehingga para penguasa dan orang-orang kaya membuka pintu-pintu mereka bagi para ilmuan. Orang-orang terkenal sering sekali berkumpul di mesjid untuk membahas persoalan-persoalan ilmiah dan hubungan dengan kesusastraan. Para ilmuan itu sendiri acap kali mengadakan pertemuan (majlis) di antara mereka untuk berdiskusi (munadzharah). Kadang kadang pertemuan itu dilakukan di masjid sebagai pengganti ceramah. 
Tahapan-tahapan yang sangat sulit dialami pada saat penulisan buku pada masa awal Islam. Kesulitan ini terlihat dimana para penulis harus membaca sendiri sendiri karyanya kepada masyarakat umum dan dibacakan lagi sampai tiga kali secara umum dengan teknik versi berbeda. Hal ini dilakukan untuk menyempurnakan karya penulis agar diakui kesahihannya secara luas. Selanjutnya tahap terakhir adalah pemberian pengesahan untuk naskah akhir yang telah melewati semua tahapan mentashihan (Masruri, 2006: 60). Banyak hal yang dilakukan oleh ilmuan terhadap buku-bukunya, baik dalam mendiktenya maupun dalam mendengarkanya ketika dibacakan. Penyalin harus membcakan hasil salinannya untuk memperoleh pengesahan. Seorang yang bernama Al-Ziyadi membacakan karya tata bahasa Al-Sibawayh kepada pengarangya, namun ia tidak menyelesaikannya sehingga ia harus menyerahkannya (rawa'an) wewenangnya kepada orang lain (Masruri, 2006: 60). Pengarang masa lalu bisa saja merawikannya kepada ilmuan lain yang mendiktekannya karya tersebut, dengan cara yang sama seperti jika ilmuwan itu mendiktekan karyanya sendiri. Dengan cara inilah AlTabari sebagai tokoh ilmuan muslim pada masa itu mendiktekan karyanya Tirimmah langsung dari ingatannya di Masjid 'Amr di Kairo.

Penulisan dan penyalinan karya-karya Ilmuan pada masa itu tidak bisa kita samakan dengan masa kini yang dapat menduplikasi karya-karya sebanyak mungkin dengan mudah. Betapa sulitnya para ilmuan pada masa itu untuk melakukan pembukuan hasil dari karyanya agar dapat dimanfaatkan oleh masyarakat dan bagi peradaban Islam dengan beberapa cara untuk bisa tersampaikan mulai dari menulis dengan media-media yang tidak lazim lagi 
digunakan di zaman sekarang, mendiktekan dan mendengarkan secara cermat untuk mendapatkan isi yang shahih. Hal ini semua tentu dapat menjadi sebuah renungan bagi kita semua untuk senantiasa menghargai dan mengkaji karya-karya mereka sehingga dapat mengahasilkan sebuah ide-ide baru yang relevan bagi peradaban Islam di era kekinian.

Mengenai keberadaan Perpustakaan pada awal Islam terdapat banyak pendapat yang menyatakan awal mula pertumbuhan dan perkembangan perpustakaan pada masa klasik. Menurut Azami, (Rifai, 2008: 60) Perpustakaan di dunia Islam berdiri sekitar abad pertama Hijriah. Pada abad itu didirikan Peprustakaan umum oleh. Abd al-Hakam bin Amr bin Abdullah bin Sufwan al-Jumhi yang memiliki koleksi buku lengkap dengan fasilitas penyimpanan seperti rak, ruang bermain anak. Terdapat juga perpustakaan khusus yang didirikanj oleh Abd al-Rahman bin Abu Laila yang diperuntukan membaca Al-Quran yang di dalamnya terdapat juga mushaf-mushaf yang tersedia untuk para Qura'.

Berbagai literatur menyebutkan bahwa Khalifah Umar Bin Abdul Aziz adalah khalifah dari Bani Umayah yang paling terkenal dengan ketaatannya terhadap agama, kesederhanaan, dan sangat mencintai ilmu dan ulama (Rifai, 2013: 62). Pendapat ini merupakan pendapat yang paling diakui di kalangan para ahli sejarah Pedersen (1996), Quraishi (1970), dan Ibn Nadim (1970) menyatakan bahwa perpustakaan yang pertama adalah perpustakaan Khlid Ibn Yazid, ini merupakan pendapat yang paling diakui.

Khalid Ibn Yazid Ibn Muawiyah mendirikan perpustakaan Islam pertama yang memiliki koleksi yang besar dan teratur. Pendirian perpustakaan ini menurut 
pakar sejarah didasari atas kesedihan dan kekecewaannya karena tidak terpilih sebagai khalifah. Khalid Ibn Yazid disebut sebagai seorang yang sangat bijaksana dari keluarga Marwan. Pada masa Yazid diperintahkan para ahli filsafat Yunani yang bermukim di Mesir agar menterjemahan karya-karya Yunani tersebut ke dalam bahasa Arab dan penerjemahan ini menurut para ahli sejarah merupakan titik awal pentarjamahan literatur dalam dunia Islam pada masa itu.

Khalid Ibn Yazid menjadi pelopor jika dihubungkan dengan sejarah kepustakaan Islam pada masanya, sehingga kepustakaan Islam terus berlanjut dari akhir abad ke-7 dan paruh pertama pada abad ke-8 dengan indikator keberhasilan dinasti Umayah dalam menkoleksi, menyalin, dan mentarjemahkan berbagai literature ke dalam bahasa Arab dari berbagai manuskrip berbahasa Yunani. (Masruri, 2006: 62). Berdasarkan pendapat para ahli sejarah tentang berdirinya perpustakaan dalam dunia Islam tentunya pendapat tersebut saling menguatkan satu sama lain terkait dimana dan oleh siapa perpustakaan pertama kali didirikan. Intinya bahwa kepustakaan dan perpustakaan Islam jauh telah ada dan berdiri sebelum kemajuan peradaban perpustakaan di dunia Barat. Keberadaan perpustakaan pada masa itu tidak hanya dijadikan sebagai tempat untuk menyimpan dan melestarikan karya-karya klasik akan tetapi perpustakaan dijadikan sebagai tempat penerjemahan karya-karya keilmuan Yunani dan keilmuan lainnya seperti yang dilakukan oleh Khalid Ibn Yazid. Berdasarkan pendapat sebagaimana yang penulis kutip di atas, tidak ditemukan nama jelas dari perpustakaan yang didirikan oleh Abd al-Hakam maupun perpustakaan yang didirikan oleh Khalid Ibn Yazid. 
Kekhalifahan Bani Abbasiyah memiliki inisiatif dan termotivasi dalam mendirikan lembaga informasi sebagai pusat ilmu pengetahuan dan peradaban Islam. Untuk itu, Perpustakaan Baitul Hikmah secara resmi dibangun sebagai tanda bahwa kekhalifahan pada masa itu sangat menjunjung tinggi ilmu pengetahuan. Fungsi pokok dari Baitul Hikmah adalah penyimpanan berbagai literatur dan pelayanan berbasis inklusi sosial dan sebagai pusat komunikasi keilmuan. Keberadaan Khizanah al-Hikmah (Hazanah Kebijaksanaan) pada masa Harun Ar Rasyid, bukan hanya difungsikan sebagai perpustakaan tetapi juga sebagai pusat untuk penelitian bagi para ilmuan. Tahun 815 M al-Ma'mun melakukan improfisasi kelembagaan dan memodifikasi perpustakaan tersebut menjadi Bait alHikmah. Al-Ma'mun menjadikan perpustakaan ini sebagai pusat riset keilmuan dalam bidang ilmu matematika, dan ilmu astronomi (Qalyubi, 2007: 50). Menurut Hak, (2015: 84-85), pendirian Bait al-Hikmah terjadi pada masa pemerintahan Khalifah Harun al-Rasyid sekitar awal abad k3 H/awal abad ke-9 (789-809 M). Pada masa ini terjadi peningkatan keilmuan yang sangat pesat dalam Islam, baik ilmu-ilmu keagamaan, kesusastraan \& kesenian, filsafat, Kimia, Astronomi, dan teori Al-Jabar.

Perpustakaan Bait al- Hikmah memiliki banyak menuskrip yang didatangkan dari raja Bayzantium, dan ini menunjukan bahwa khalifah al-Makmun memiliki hubungan dengan raja-raja kontantinopel dimana Bait Al Hikmah bayakan menyimpan karya Plato, Aristoteles, Hippocrates, Glen, Eulid, Ptolemi, dan lain-lain. Al-Makmun menginstruksikan kepada Ya'qub bin Ishaq al-Kindi untuk mentarjamahkan karya ilmuan Yunani ke dalam bahasa Arab, ia telah berhasil menulis 282 buku tentang filsafat, 
musik, kedokteran. Terdapat juga literatur langka yang telah dikumpulkan dari berbagai wilayah seperti India, Iran, Mesir, dan Syiria. Khalifah yang berkuasa pada masa itu juga mengirim seorang yang bernama Hajjaj bin al-Batriq ke Negara-negara kerajaan Romawi untuk menghimpun karya ilmuan yang bernama Qusta bin Luqa, sedangkan Hunayn bin Ishaq diutus untuk mencari Kitab al-Barhan di Mesir, Syiria, dan, Damaskus, hingga ke negara Palestina.

Banyak ilmuan yang dilibatkan dalam kegiatan tarjamah terhadap karya-karya Yunani dan Romawi ke dalam bahasa Arab. Ilmuan tersebut merupakan tiga saudara dari Banu Musa; yaitu Muhammad, Ahmad, dan Hasan. Selain ilmuan ini ada juga Yahya bin Abi Mansur dan Kristen Qusta bin Luqa, Sabian Thabit bin Qurra, serta Hunayn bin Ishaq. Selanjutnya diikuti oleh Yuhanna bin Musawaiyh serta Muhmmad bin Musa al-Khawarizmi mereka juga melakukan kegiatan mentarjamahkan berbagai literature keilmuan dari Yunani dan Romawi ke dalam bahasa Arab (Masruri, 2006: 77-78). Melihat indikasi ini, tentunya kebijakan khalifah al makmun pada masa itu memberikan kesempatan untuk melakukan pengembangan ilmu pengetahuan bukan hanya pengetahuan agama melainkan keilmuan yunani kuno berupa ilmu filsafat yang dikemukakan aristoteles dan plato pada masa itu.

Andaya dorongan dan kecintaan terhadap ilmu pengetahuan dan pendidikan mendorong perlunya mendirikan lembaga yang menjadi wadah pengembangan keilmuan hingga abad ke-2 $\mathrm{H}$. Banyak koleksi perpustakaan terbuka untuk masyarakat mum ataupun terbatas telah didirikan di berbagai wilayah kekuasaan Islam pada masa itu. Keberadaan perpustakaan Islam sangat menarik untuk diungkap di kalangan umat Islam, dan 
terlihat bahwa perpustakaan Islam telah mengalami perkembangan pesat setelah mengalami transisi pada abad pertama. Untuk itu, dapat digambarkan dengan jelas bagaimana penyebaran perpustakaan Islam sebagai berikut; Pertama, kemajuan peradaban Islam karena adanya akselerasi dan adaptasi dengan karakter dan kultur Yunani, Syiria, dan Persia dan bahkan masuknya peradaban India dan Cina. Ini juga dipengaruhi perdagangan global di antara Negara-negera tersebut. Kedua, faktor temuan media tulis berupa kertas dari Cina sekitar akhir abad ke-8, sehingga mempengaruhi terhadap pembuatan buku-buku Arab dan aktivitas pengumpulan buku-buku yang juga merupakan titik awal pengaruh terhadap percetakan dan penerbitan di Eropa dan Barat pada umumnya (Masruri, 2006: 62).

Menurut Jhon F. Draper sebagaimana dijelaskan dalam Intellectual Development of Europe dilukiskan dengan penuh kagumannya orang-orang Islam mendirikan perpustakaan-perpustakaan di pusat kota utama. Sekitar abad kedua hijriah telah didirikan kurang lebih 70 perpustakaan. Menurut Nakosteen (1996) dalam (Rifai, 2013: 73) menjelaskan keberadaan beberapa perpustakaan penting dalam dunia Islam. Keberadaan Perpustakaan di kawasan Timur yaitu dari Baghdad hingga ke wilayah Nisabur di masa kejayaan hingga sebelum bangsa Mongol membumi hanguskannya. Menurut sejarah terdapat perpustakaan yang berada di wilayah itu yaitu:

1. Perpustakaan Umar al-Wakidi (736-811 M), diperkirakan seratus dua puluh ekor untan untuk membawa koleksi buku tersebut.

2. Bait al-Hikmah dari al-Ma'mun.

3. Dar al-Ilm dari Ardeshir (991 M)

4. Perpustakaan Madrasah al-Mustanshiriyah (1233 M) 
5. Perpustakaan Madrasah Nizhamiyah (1064 M).

6. Perpustakaan Madrasah al-Baiqani dengan koleksi diperkirakan enam puluh tiga keranjang dan dua kopor.

7. Perpustakaan Muhammad Ibn Husain dari Haditsa dengan manuskrip-manuskrip langka yang disimpan pada tempat yang aman..

\section{Faktor-faktor yang mendorong pertumbuhan dan Perkembangan Perpustakaan Islam}

Sejarah mencatat bahwa kegiatan intelektual kurang menjadi perhatian pada masa pemerintahan kekhalifahan Umayah. Pada masa pemerintahan Umayah lebih fokus pada perluasan kekuasaan wilayah, sehingga tidak terlalu memperhatikan pengembangan keilmuan seperti pada masa Daulah Abbasiyah. Pada Abbasiyah perhatian pada pengembangan keilmuan yang relatif stabil sehingga kebijakan pemerintahan lebih mendorong pada upaya untuk mencapai pengembangan keilmuan dan kesejahteraan masyarakat dalam mencapai tingkat kemajuan yang sangat pesat dan membanggakan pada masanya, sehingga banyak sejarawan kemudian menyebutkan masa Daulah Abbasiyah merupakan masa keemasan yang pernah dicapai umat Islam. Perestasi ini bukan berarti telah terciptanya tatanan kehidupan social dan ekonomi yang mapan, akan tetapi aspek perkembangan ilmu pengetahuan yang mencapai puncak kejayaan. (Rifai, 2013: 68). Menurut Hak, (2015: 85) terdapat tiga faktor pendukung utama mengapa perkembangan perpustakaan dan kepustakaan Islam begitu pesat, baik pada masa Daulah Abbasiyah di Baghdad maupun Daulah Bani Ummayyah II di Andalusia. Pertama, dukungan penuh dan peran serta pemerintahan, dukungan penuh dan peran serta pemerintahan Islam, khususnya para khalifah Abbasiyah baik secara material maupun usaha dan 
kebijakan yang dijalankannya. Kedua tradisi penerjemahan buku-buku berbahasa Asing non Arab yang terus berkembang, dan dinamisasi jaringan kebudayaan TimurBarat, terutama di negeri-negeri yang jauh sebelumnya sudah memiliki peradaban, semua itu akibat dari difusi kebudayaan, penetrasi dan akulturasi budaya Arab dan non Arab; Yunani dan Persia, Romawi, Syiria-Nestorian, Mesir, India dalam kebudayaan, khususnya keilmuan dan kepustakaan dan ketiga, adalah masyarakat Muslim sangat antusias dalam hal ini, baik Arab maupun non Arab, khususnya ilmuan agama, cendikiawan, dan sastrawan dalam mencintai ilmu, memiliki jiwa untuk melakukan petualangan dan pengembaraan dalam rangka riset ilmu pengetahuan di berbagai bidang keilmuan, sehingga menghasilkan inovasi dan produktifitas karya yang dapat dinikmati oleh semua kalangan hingga saat ini.

Adanya perhatian dari pemerintah dan masyarakat luas terhadap ilmu pengetahun, dan penghormatan kepada para cendikiawan atau ulama merupakan karakter mewarnai pada masa itu, sehingga tidak heran jika berdirinya berbagai perpustakaan pada masa itu. Selain masyarakat yang sangat memperhatikan ilmu pengetahuan, para penguasa pada masa itu memberikan kebebasan berkreativitas berpikir di kalangan masyarakat muslim sehingga pada masa itu melahirkan ilmuan-ilmuan muslim dengan karyakaryanya yang sangat fenomenal sehingga dapat kita rasakan karya-karya mereka sampai pada abad ini (Hak, 2015: 71). Oleh karena itu, pemerintahan Khalifah Abbasiyah pada masa itu berinisiatif untuk mendirikan lembaga-lembaga ilmu pengetahuan termasuklah perpustakaan. Kebijakan ini bertujuan memfasilitasi bagi masyarakat yang haus akan ilmu pengetahuan untuk 
mengembangkannya secara terus menerus sehingga terbangun sebuah komunikasi keilmuan secara terus menerus. Untuk itu, pemerintah mendirikan Bait Al-Hikmah.

Dorongan pendirian Bait Al-Hikmah juga didasari atas keinginan untuk mencontoh lembaga-lembaga lain yang telah didirkan oleh non Islam yakni gondhesaphur ia merupakan tokohnya georgius Gabriel yang pada masa khalifah al-Mansur pernah ditunjuk menjadi kepala di sebuah rumah sakit. Ia juga aktif menerjemahkan karyakarya yunani (Hourani, 2004: 56). Menurut Yatim, (2008: 3) terdapat motivasi lainnya dalam pembentukan lembaga Baitul Hikmah adalah faktor-faktor sebagai berikut:

a. Kekayaan negara yang melimpah dan apresiasi khalifah al Makmun sangat tinggi terhadap ilmu pengetahuan dan kebudayaan, seperti ilmu kedokteran, filsafat, astronomi, dan lain-lain, dan juga ketertarikan terhadap kesenian musik. Adanya kekayaan dan keinginan ini melahirkan sebuah pemikiran yang sangat mendukung dalam mengembangkan pendidikan lebih maju dalam membagun peradaban masyarakat yang ternyata pemikiran ini mendapat sambutan yang positif dari para pembantunya dan dari masyarakat.

b. Bentuk apresiasi yang sangat tinggi dari mayoritas dari lapisan masyarakat terhadap kegiatan dalam memajukan keilmuan, sehingga mereka saling bahu membahu tanpa ada batasa berbedaan agama, etnis, dan status social serta tanpa adanya tekanan psikologis bagi masyarakat

\section{Peran Kepustakaan dan Perpustakaan Islam terhadap Peradaban Islam}

Keberadaan perpustakaan pada awal Islam banyak memberikan dampak yang siknifikan terhadap peradaban Islam karena karya-karya yang dikelola pada masa itu 
bukan hanya karya-karya keislaman saja, akan tetapi banyak karya-karya non keislaman hasil penerjamahan para ilmuan misalnya dari bahasa Yunani ke dalam baha Arab yang kemudian memberikan manfaat yang luar biasa dalam membangun peradaban Islam.

Keberadaan perpustakaan pada awal Islam hingga pada masa kejayaan Islam telah menghasilkan karya-karya baik itu ilmu keagamaan maupun science sehingga pada masa itu banyak para ilmuan-ilmuan Muslim memberikan kontribusinya terhadap kemajuan Islam melalui karya-karya mereka. Hal ini terjadi karena pada masa itu juga tidak terlepas dari pemberian kreativitas dan kebebasan berpikir untuk menghasilkan sebuah karya-karya fenomenalnya sehingga dapat memberikan sebuah sentuhan tersendiri terhadap dinamika perkembangan ilmu pengetahuan di dinia Islam.

Berdasarkan hasil penelusuran para sejarawan tentang peran perpustakaan dalam membangun keberadaban Islam pada masa itu dapat dilihat dari berbagai literature sebagaimana yang penulis kutip (Masruri, 2006: 69)

1. Pusat belajar (Learning Center)

Masa dekada pemerintahan Khulafauurasyidin merupakan fase awal dari pencatatan atau tradisi tulisan yang berkaitan dengan wahyu dan Hadits Rasul hal ini belum tampak adanya kejelasan mengenai keberadaan perpustakaan pada masa itu. Pada fase setelahnya sudah terlihat jelas bahwa perkembangan yang sangat siqnifikan di bidang pendidikan ketika pada Bani Umayyah dan perkembangan Ilmu pengetahuan sangat menonjol juga pada masa Abbasiyah.

Sayangya, kemajuan peradaban Islam pada masa itu kurang tereksplor kepada masyarakat saat ini dan 
kurang diambil ibrahnya dalam membangun ilmu pengetahuan dan peradaban dunia. Perpustakaan yang sejatinya merupakan pusat dari sumber ilmu pengetahuan masih dianggap sebagai tempat yang sangat usang dan terkadang dianggap sebagai lembaga terbelakang dan kurang memberikan kontribusi dalam peradaban.

2. Pusat Penelitian

Kemegahan Bait Al-Hikmah tidak terlepas dari kontribusi hasil penelitian yang dilakukan para ilmuan muslim pada masa Abbasiyah. Koleksi yang dimiliki pada perpustakaan Bait Al-Hikmah cukup besar dan lengkap. Ilmuan pada masa itu memiliki trik dan strategi dalam hal pengembangan ilmu pengetahuan. Trik dan strategi itu dilakukan dengan melakukan kunjungan ke berbagai perpustakaan dengan maksud mencari berbagai literatur keilmuan untuk dirumuskan agar memperoleh suatu cabang ilmu baru. Untuk itu, kegiatan seperti ini dapat menjadi sebuah stimulus untuk para peneliti masa kini untuk terus melakukan sebuah penelitian untuk menghasilkan karya-karya yang berisi informasi untuk memberikan kontribusi keilmuan bagi peradaban manusia. Pada masa itu telah dikenal keilmuan yang bersifat keduniawian seperti kedokteran, politik dan sebagainya. Hal ini tidak terlepas dari hasil penelitian para ilmuan terdahulu.

3. Pusat Penerjemahan

Perkembangan keilmuan pada masa itu diawali juga dengan menggali keilmuan dari Yunani kuno sebagai jembatan awal. Maraknya kegiatan penerjemahan ke dalam bahasa Arab menjadi langka utama untuk mengembangkan keilmuan Islam pada masa itu, 
sehingga lambat laun perkembangannya sangat siknifikan dengan ditandai munculnya para ilmuanilmuan generasi berikutnya. Berdasarkan pembahasan sebagaimana yang penulis ulas pada pembahasan sebelumnya, Khalid Ibnu Yazid merupakan orang pertama yang melakukan menerjemahan berbagai karya ke dalam bahasa arab (meninggal tahun $656 \mathrm{M}$ ). Berbagai sumber mencatat bahwa bentuk perhatian Ibn Yazid terhadap ilmu pengetahuan adalah menterjemahkan karya-karya lama di bidang ilmu astronomi, ilmu kimia, dan ilmu kedokteran.

4. Pusat Penyalinan Buku

Perkembangan perpustakaan di dunia Islam ditandai dengan munculnya alat penyalin buku dalam sebuah perpustakaan di era abad pertengahan. Kegiatan ini merupakan kebanggaan tersendiri bagi kaum Muslimin pada masa itu, walaupun alat pencetak seperti yang ada di era modern belum terlihat pada masa itu, namun pencetakan yang ada dapat dimanfaatkan sebaik-baiknya dan membantu meperbanyak hasil karya-karya ilmuan sehingga dapat didistribusikan ke daerah lain.

Penulis mengatakan bahwa umat islam pada masa itu pernah berada pada masa kejayaan yang tak tertandingi dilihat dari awal perkembangan ilmu pengetahuan yang telah banyak kontribusinya hingga sampai saat ini. Untuk itu, bagi generasai berikutnya khususunya ilmuan muslim untuk selalu berkreasi untuk mengembangkan keilmuan yang telah diwariskan oleh ilmuan pada masa lalu yang selama ini masih dianggap mengalami stagnasi dibandingkan dengan negara-negara barat seperti eropa yang jauh lebih maju 
dan hendaknya perpustakaan juga dapat menjadi sebuah pusat dokumentasi terhadap karya-karya yang telah dihasilkan oleh pendahulu-pendahulu kita agar karya-karya tersebut dapat terus dikembangkan oleh generasi berikutntya. 


\section{KESIMPULAN}

Cikal bakal atau rintisan kepustakaan diawali dengan pencatatan teks yang bersifat keagamaan dan non keagamaan. Perkembangan perpustakaan terus beransur pada masa pemerintahaan Dinasti Umayah dengan berdirinya al-Zuhri sebagai perpustakaan pertama. Pada periode berikutnya yaitu pada masa pemerintahan Khalifahan Bani Abbasiyah terdorong para penguasanya untuk mendirikan sebuah perpustakaan. Faktor-faktor pendorong kemajuan kepustakaan dan perpustakaan Islam pada masa itu tidak terlepas dari kebijakankebijakan dan kepedulian pemerintahan pada masa itu. Kebijakan pada masa itu khususnya pada masa Abbasiyah lebih menonjolkan perkembangan ilmu pengetahuan dengan mengirim para ilmuan untuk melakukan sebuah riset terhadap ilmu-ilmu yang ada di Yunani yang kemudian diterjemahkan, kekayaan negara yang mendukung kesejahtraan masyarakat, dan kesadaran akan pentingnya ilmu pengetahuan bagi masyarakat. Peran perpustakaan pada masa itu dapat menjadi sebuah kreatifitas bagi individu untuk mengembangkan potensi-potensi yang ada dengan menjadikan perpustakaan sebagai pusat penerjemahan, pusat pembelajaran, dan pusat penelitian. 


\section{DAFTAR PUSTAKA}

Hak, Nurul. (2015). Kepustakan, Perpustakaan dan Peradaban Dalam Dunia Islam (Klasik, Pertangahan Modern). Yogyakarta: Pascasarjana UIN Sunan Kalijaga Yogyakarta.

Hourani, Albert. (2004). Sejarah Bangsa-bangsa Muslim, Bandung: Mizan Pustaka.

Masruri, Anis dkk. (2006). Sejarah Peprustakaan Islam, Yogyakarta: Fakultas Adab UIN Sunan Kalijaga.

Pedersen, J. (1996). Fajar Intelektualisme Islam"Buku dan Sejarah Penyebaran Informasi di Dunia Arab Islam, Bandung: Penerbit Mizan.

Qalyubi, Syihabuddin, dkk. (2007). Dasar-Dasar Ilmu Perpustakaan dan Informasi, Yogyakarta: Jurusan Ilmu Perpustakaan dan Informasi Fakultas Adap UIN Yogyakarta.

Rifai, Agus.(2013).Perpustakaan Islam"Konsep, Sejarah, dan Kontribusinya dalam membangun Peradaban Islam Klasik", Jakarta: Rajawali Press.

Rohyanti Zulaikha,Sri. (2008). Kontribusi Islam Atas Peradaban"Sikap dan Kaitan Islam dengan Perpustakaan dalam Pendistribusian Informasi",Yogyakarta: Perpustakaan Digital UIN Sunan Kalijaga.

Yatim, Badri. (2008). Sejarah Paeradaban Islam, Jakarta: Rajawali Pers.

Zuhrah, Fatimah. (2008). Perpustakaan Sebagai Pusat Studi Islam, Jurnal Iqra' Volume 02 No. 02. diakses dari http://jurnal.uinsu.ac.id/index.php 20 Februari 2020. 